\title{
Effect of Peers Assessment and Short Report in Year III Laboratory Course
}

\author{
Norliza Abd Rahman ${ }^{1} \&$ Noorhisham Tan Kofli ${ }^{1,2}$ \\ ${ }^{1}$ Department of Chemical \& Process Engineering, Faculty of Engineering and Built Environment, Universiti \\ Kebangsaan Malaysia, Selangor, Malaysia \\ ${ }^{2}$ Centre for Engineering Education Research, Engineering, Faculty of Engineering and Built Environment, \\ Universiti Kebangsaan Malaysia, Selangor, Malaysia \\ Correspondence: Norliza Abd Rahman, Department of Chemical \& Process Engineering, Faculty of Engineering \\ and Built Environment, Universiti Kebangsaan Malaysia, 43600 UKM Bangi, Selangor, Malaysia. Tel: \\ 60-389-216-115. E-mail: liza@eng.ukm.my
}

Received: February 7, 2013 Accepted: April 7, 2013 Online Published: May 13, 2013

doi:10.5539/ies.v6n6p23 URL: http://dx.doi.org/10.5539/ies.v6n6p23

\begin{abstract}
Laboratory course in Biochemical and Chemical Engineering Programmes at the Department of Chemical and Process Engineering, Faculty of Engineering and Built Environment, has introduced the peer group evaluation, presentation, reports submitted by groups/individual as assessment tools for 3rd year laboratory course. The experiments for the course is done in group and students has to submit two types of reports called long report (group) and short report (individual). The major problem of the group effort is that there are students who did not cooperate and participate in the experiment which in turn affects other students mark in the group. Peer group evaluation and short reports contributed up to $5 \%$ to $45 \%$ to the total marks of the course respectively. In this study, we evaluated marks of peer group and short report in overall performance of a student. Results indicated that both marks can be used to differentiate student who actively participate in the experiment with those who is a passive member of the team.
\end{abstract}

Keywords: group work, short reports, laboratories, questionnaires

\section{Introduction}

Every student in the engineering department is compulsory to undergo laboratory courses or experiments aimed at understanding the theory they have learned during the lecture. Laboratory course is vital in teaching and and developing students skills since it can provide students an arena for training towards a good work ethic (Mooney, 2001), to improve skills such as communication (Felder \& Brent, 2003 and also promote critical thinking (Ruthven, 1996).

In the department, the laboratory classes in organized in group of 3 to 4 students per group which requires them to practice good team skills. While running the experiments, the laboratory course could become a venue to foster teamwork skill (Noorhisham \& Norliza, 2011; Norliza et al, 2011; Norliza \& Noorhisham, 2010). Each group members are selected at random which includes every gender, race, and a variety of student achievement (CGPA). Unfortunately, there are some students who act as free rider by doing minimal or not participating at all but gained much since part of the marks given to the groups. To overcome the problem, evaluation for laboratory courses at year 3 in the Department of the Chemical and Process Engineering, (JKKP), has include individual (short reports), group effort (long reports) and peer evaluation. The long report normally submitted within a week of the date of the experiment while short report is submiited immediately on the same day after the student compeleted the experiment. Table 1 shows distribution of marks for long report, short report, presentation and peers assesement for this course. 
Table 1 . The evaluation and measurement performed in the laboratory

\begin{tabular}{lc}
\hline Item & Marks (\%) \\
\hline Long report (Group work) & $35-45$ \\
Short report (Individual) & $40-45$ \\
Peers assesement (Individual) & $0-5$ \\
Presentation (Group work) & $0-10$ \\
\hline
\end{tabular}

This paper aims to prove that the assessment that we practice in the department managed to differentiate those students who did not actively participate in the experiment by using data from 4 courses coded KB3512, KR3512 and KB3612, KR3612 for 1st and $2^{\text {nd }}$ semester at session 2011/2012 involving a total of 58 students from both programmes offered by the department.

\section{Method}

Two evaluation data were used in the study which marks were obtained from short reports and peer evaluations.The distribution of these marks are depicted in Table 1. The data were gathered from two programmes offered by the department which are Chemical (KK) and Biochemical (KB) degree programme.

\subsection{Peer Evaluation}

The students were asked to judge and marks their team members honestly based in the evaluation form which is normally distributed at the completion of the course. The peer evalution form is shows in Table 2 which mainly caters team work skills.

Table 2. Sample of Peers Evaluation

\begin{tabular}{llll}
\hline PO Examiner Name : & MATRIXS NO.: & Group: \\
\hline Likert assessment of the level of cooperation: & VERY AGREE & $\mathbf{5}$ & $\mathbf{4}$ \\
$\mathbf{2} \mathbf{1}$ DO NOT AGREE & & & \\
(Please provide appropriate assessment score in the appropriate box) & \\
\hline & $\begin{array}{l}\text { Student Name (Group } \\
\text { CRITERIA }\end{array}$ & \multicolumn{3}{l}{ Member) } \\
\end{tabular}

Ability to build a team to achieve a common goal

Ability to be a leader and a follower.

Demonstrate the ability to respect and accept the opinion of others.

6 Ability to accept diversity within the group.

Demonstrate the ability of being involved and contribute to the planning and coordinating the work of the group.

Responsible for the results of the group.

Ability to assist other partners proactively. 


\subsection{Short Reports}

Short report is a report of an individual work which contributed $40-45 \%$ of the total marks are evaluated by the course coordinator and Table 3 refers to the assessment of the short report.

Table 3. Assessment of the short lab report

\begin{tabular}{lll}
\hline Contents & Full Marks & Actual Marks \\
\hline Problem Statements & 7 & \\
Objectives & 3 \\
Results & 30 \\
Discussions & 30 \\
Conclusion & 10 \\
Quiz & 10 \\
Neatness & 10 \\
Total & $\mathbf{1 0 0}$ \\
\hline
\end{tabular}

\section{Results}

\subsection{Peer Assesement Performance}

The result of the KB programme was encouraging when all students (22 students) rated their peers to maximum marks $(100 \%)$. Different results observed in the KK engineering program when out of 36 students, there is a student was rated less than maximum scores for both semesters as shown in Figure 1. These results indicated the method practice has successfully identify students who do not cooperate in group activities and improvement measures for the students involved can be implemented.

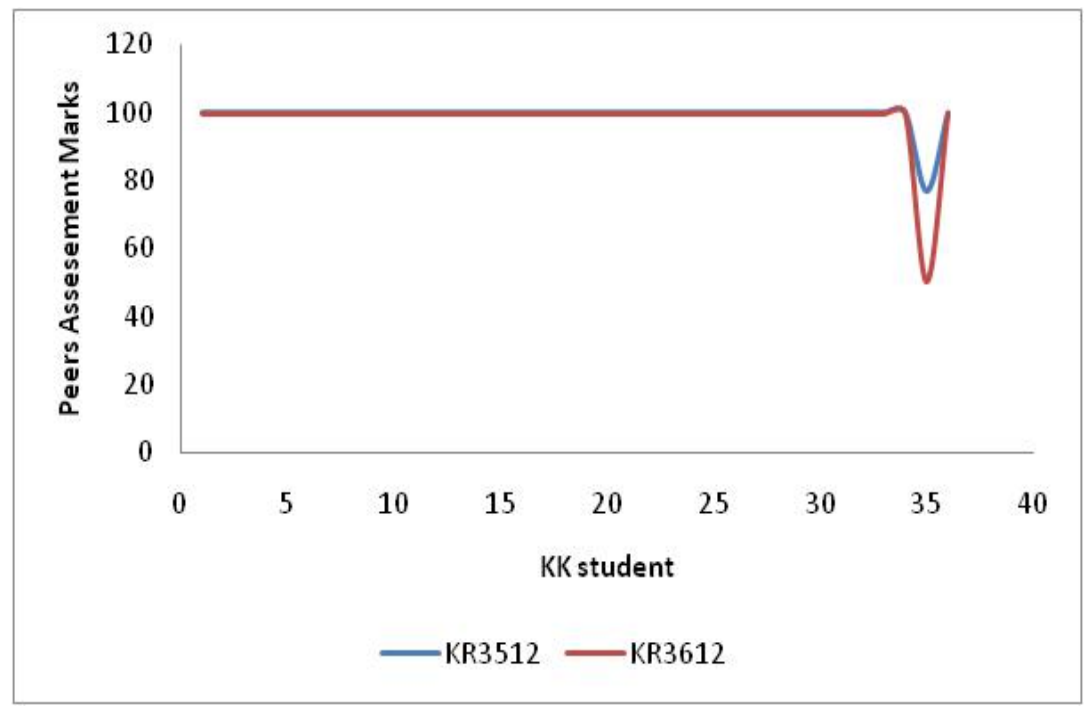

Figure 1. Peers assesement for KK student

\subsection{Short Report Evaluation}

The student submitted 4-6 short reports for their laboratory course as their individual work although the experiments were executed in groups. All students have submitted the report on time and managed to score ranges between $64-81 \%, 66-79 \%, 45-90 \%$ and $84-93 \%$ for the KR3512, KB3512, KR3612 and KB3612 respectively. Figures 2 and 3 showed the marks obtained for both programmes of KB and KK. 


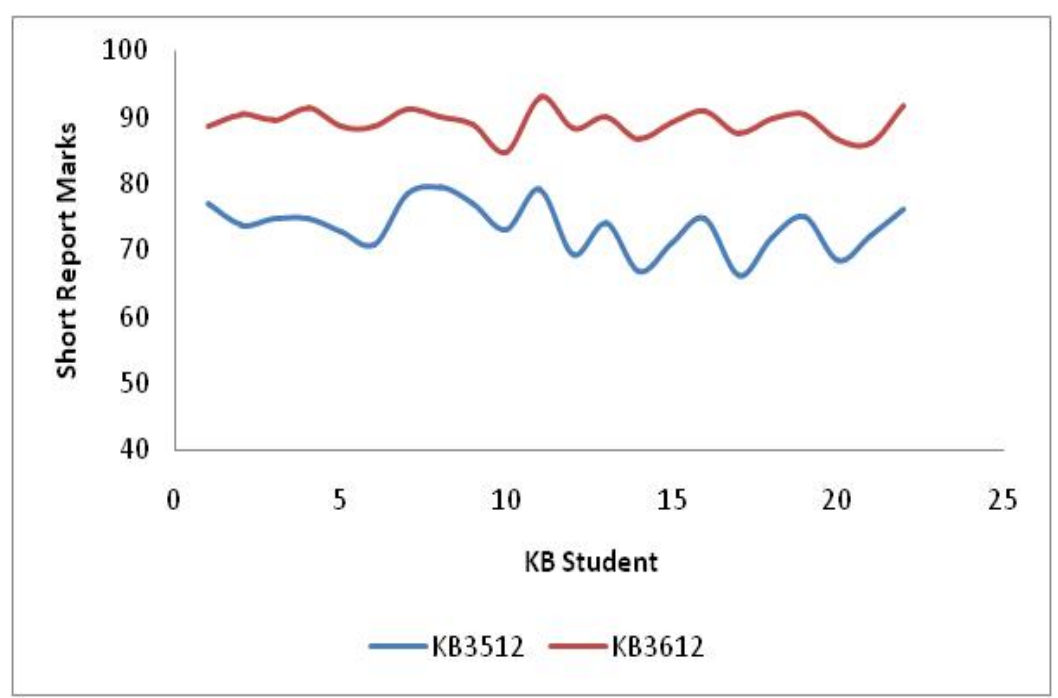

Figure 2. Short report of KB student

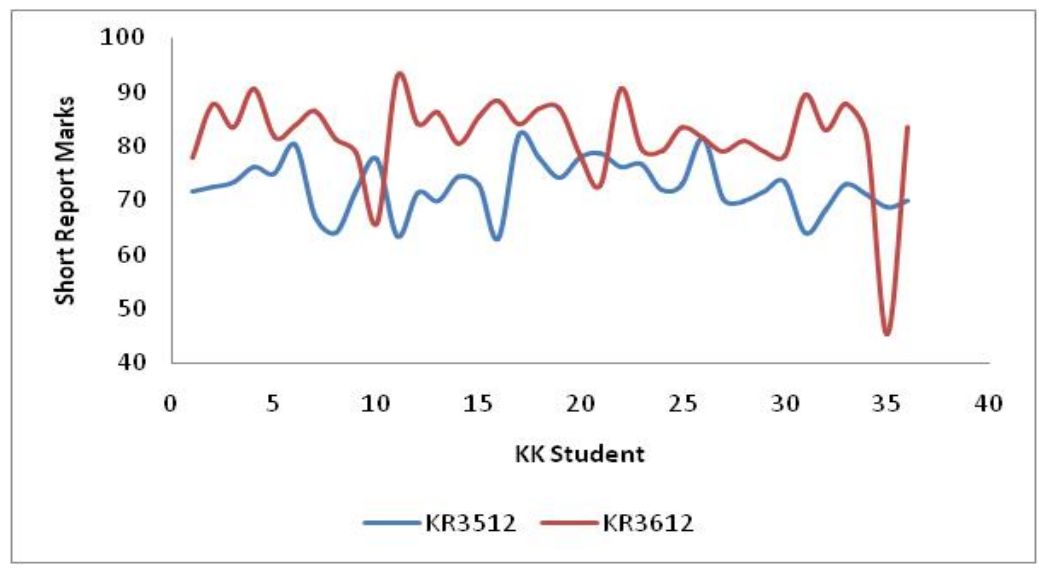

Figure 3. Short report of KK student

\section{Discussion}

Peer evaluation form is mainly focused on student perception of their team member's participation and team works. Though many of the students are skeptical in rating their peers, some students do marks their peer honestly as shown by the results from KK programme. In general, most students believed they have practice good team work skill and has managed their group well in completing the task.

In general, students of both programs have been successfully submitted their reports as are required as shown in Figure 2 and 3. Since the report must be submitted on the same date of their experiments, the isu of plagiarism could be reduced and avoided. The objective of the short report for evaluating individual performance and was successfully implemented by giving the mark portion up to $45 \%$ of the overall mark balancing the group report marks (up 40\%).

Figures 2 shows the student reports for KB student (KB3512 and KB3612) for semester I ranges from 66-78\% though higher marks obtained in the $2^{\text {nd }}$ semester marks (84-93\%). Similar performances for KK student were also observed for KR3512 and KB3612 except for a few students which clearly indicated in Figure 3. In general, the higher marks obtained from $1^{\text {st }}$ to $2^{\text {nd }}$ semester might be due to that fact that students have more understanding on how to manage their course. From Figure 1 and 3, the student who did not participate obtained lower marks in peer evaluation, lower individual marks and only dependent on their groups work. The student obtained low overall marks and shown in the grade obtained indicated portion given of each components are sufficient to differentiate the student.

In general, both peers evaluation and short reports could be used as student performance in their laboratory course. With proper marks distribution it can also differentiate student participation by looking at their grades. 


\section{Acknowledgements}

The authors would like to thank Universiti Kebangsaan Malaysia (UKM- PTS-2012-159) for funding this study.

\section{References}

Felder, R. M., \& Brent, R. (2007). "Cooperative Learning”, in Active Learning: Models from the Analytical Sciences, In P. A. Mabrouk (Ed.), ACS Symposium Series 970, Chapter 4, American Chemical Society, Washington DC, pp. 34-53.

Felder, R. M., \& dan Brent, R. (2003). Designing and Teaching Courses to Satisfy the ABET Engineering Criteria. J. of Eng. Edu., 7-25.

Mooney, K. G. (2001). Challenges Faced by the Pharmaceutical Industry: Training Graduates for Employment in Pharmaceutical R\&D., European J. of Pharma. Sci., 12, 353-359. rma. Sci., 12, 353-359.

Noorhisham Tan Kofli, \& Norliza Abdul Rahman. (2011). The Open Ended Laboratory For Measurement Of Communication Skill For Chemical/Biochemical Engineering Students. Procedia Social and Behavioral Sciences, 18(2011), 65-70. http://dx.doi.org/10.1016/j.sbspro.2011.05.010

Norliza Abd. Rahman, \& Noorhisham Tan Kofli. (2010). Striving for Excellence Governing Practice Through Action Research. Bab 8. Penerbit Universiti Kebangsaan Malaysia, 111-119.

Norliza Abd. Rahman, Noorhisham Tan Kofli, Mohd Sobri Takriff, \& Siti Rozaimah Sheikh Abdullah. (2011). Comparative Study between Open Ended Laboratory and Traditional Laboratory. IEEE EDUCON Education Engineering 2011 - Learning Environments and Ecosystems in Engineering Education, 1-5.

Pfeiffer, W. S. (2003). Technical Writing: A Practical Approach. NewJersey: Prentice Hall.

Ruthven, D. M. (1996). Chemical Engineering Education: A Personal View. Chem. Eng. Sci., 51(18), iii-iv. http://dx.doi.org/10.1016/0009-2509(96)00317-X 